\title{
Gene Expression Profiles Deciphering the Pathways of Coronatine Alleviating Water Stress in Rice (Oryza sativa L.) Cultivar Nipponbare (Japonica)
}

\author{
Wei Gao, Chunxin Yu, Lin Ai ${ }^{-}$, Yuyi Zhou and Liusheng Duan* \\ Engineering Center for Plant Growth Regulators MOE, College of Agronomy and Biotechnology, \\ China Agricultural University, Beijing 100193, China; wei1227@126.com (W.G.); yuchunxin@cau.edu.cn (C.Y.); \\ 18601272095@163.com (L.A.); zhouyuyi711@126.com (Y.Z.) \\ * Correspondence: duanlsh@cau.edu.cn
}

Received: 29 March 2019; Accepted: 24 April 2019; Published: 23 May 2019

\begin{abstract}
Coronatine (COR) is a structural and functional analog of methyl jasmonic acid (MeJA), which can alleviate stress on plant. We studied the effects of COR on the drought stress of rice (Oryza sativa L.). Pre-treatment with COR significantly increased the biomass, relative water and proline content, and DPPH (1,1-diphenyl-2-picrylhydrazyl)-radical scavenging activity, decreased the electrolyte leakage and MDA (Malondialdehyde) content in order to maintain the stability of cell membrane. Meanwhile, we determined how COR alleviates water stress by Nipponbare gene expression profiles and cDNA microarray analyses. Seedlings were treated with $0.1 \mu \mathrm{mol} \mathrm{L}{ }^{-1} \mathrm{COR}$ at the three leafed stage for $12 \mathrm{~h}$, followed with $17.5 \%$ polyethylene glycol (PEG). Whole genome transcript analysis was determined by employing the Rice Gene Chip (Affymetrix), a total of 870 probe sets were identified to be up or downregulated due to COR treatment under drought stress. Meanwhile, the real-time quantitative PCR (RT-qPCR) method was used to verify some genes; it indicated that there was a good agreement between the microarray data and RT-qPCR results. Our data showed that the differentially expressed genes were involved in stress response, signal transduction, metabolism and tissue structure development. Some important genes response to stress were induced by COR, which may enhance the expression of functional genes implicated in many kinds of metabolism, and play a role in defense response of rice seedling to drought stress. This study will aid in the analysis of the expressed gene induced by COR.
\end{abstract}

Keywords: drought stress; gene expression; coronatine; phytohormone

\section{Introduction}

Rice (Oryza sativa L.) is widely cultivated as a staple crop throughout the world, and it also is a model monocot plant for molecular and genetic studies, while water deficiency is one of the most important limitations to its growth and grain yield. Shortage of water limits plant growth and crop productivity more than any other single environmental factor [1]. Drought and water deficit can decrease photosynthetic capacity, result in dehydration of plant cells, oxidative damage to chloroplasts, imbalance of photosynthesis and respiration, limit metabolic reactions, and reduce dry matter accumulation and partitioning $[2,3]$. There are several enzymatic antioxidants to eliminate activated oxygen species, such as catalase (CAT; EC 1.11.1.6), peroxidase (POD; EC 1.11.1.7), superoxide dismutase (SOD; EC 1.15.1.1), ascorbate peroxidase (APX; EC 1.11.1.11) and glutathione reductase (GR; EC 1.6.4.2), and this defence mechanism could be induced during water-deficit stress. Cell membrane stability has been widely used to estimate stress tolerance, and higher membrane stability was correlated with drought stress tolerance $[4,5]$. Drought stress may particularly trigger the formation of 
superoxide radical and hydrogen peroxide $\left(\mathrm{H}_{2} \mathrm{O}_{2}\right)$, which were paralleled by malondialdehyde (MDA) accumulation in rice [6]. MDA, which is a decomposition product of polyunsaturated fatty acids of biomembranes, is an important indicator of membrane damage [7]. The 2,2-dipenyl-1- picrylhydrazyl (DPPH)-ridical scavenging activity is closely correlated with stress tolerance [8], and has been accepted as a measure of radical-scavenging activity [9].

Chemical regulation applying plant growth substance has proved to be potentially beneficial in drought tolerance improving and water-saving agriculture [10]. Coronatine (COR) is a chlorosis-inducing non-host-specific phytotoxin produced by several members of the Pseudomonas syringae group of pathovars [11-13], and induces a wide array of effects in plants. It is a structural mimic of jasmonates, but more active than jasmonates in some functions, in plants; both share the same receptor, coronatine insensitive1 (COI1) [11,14], so coronatine can manipulate plant hormone signaling to affect defense responses [15-17]. It leads to diffuse chlorosis of leaf, anthocyanin production, ethylene (ETH) emission, auxin synthesis, tendril coiling, inhibition of root elongation and hypertrophy $[14,18,19]$. COR could stimulate the plant metabolism, produce a variety of plant toxins involved in the adjustment of low temperature, salt stress [20,21], water stress [22-25], and other adversities [26]. Both MeJA and COR can alleviate the adverse effects of drought stress and enhance the ability for water stress resistance through promotion of defense-related metabolism in cauliflower seedlings [27].

Coronatine research has focused on explaining the mechanism of coronatine in hormone pathways $[28,29]$. Recent research showed that COR interfered with the normal role of salicylic acid (SA) in the interaction with other hormones [30,31], and COR could stimulate the response induced by JA [32]. Biological assays, ultrastructural studies and gene expression studies suggest that COR induces JA biosynthesis, and impacts signaling in tomato via the jasmonic acid, ethylene, and auxin pathways. $[14,33]$. It is more noticeable that COR has been confirmed to activate the JA responsive genes, with the involvement of some signaling molecules such as hydrogen peroxide, nitric oxide, and $\mathrm{Ca}^{2+}$, to induce the production of secondary metabolites such as flavonoids, volatiles, nicotines, and alkaloids [34-36]. COR also increased the activities of active oxygen cleavage enzymes, SOD, CAT, POD and GR in two rice cultivars under drought [37]. However, few studies have focused on what the pathways of coronatine are to alleviate water stress in rice at the level of genes.

The objective of this work, therefore, was to evaluate the effects of exogenously applied COR on gene expression and its roles in drought resistance of rice. For these purposes, plants of Nipponbare which have been suffered from drought stress following COR pre-treatment were sampled for Affymetric Gene Chip analysis and RNA isolation. We investigated the changes of expressed genes by Nipponbare gene expression profiles and cDNA microarray analyses, a total of 870 probe sets were identified to be up or downregulated due to COR treatment under drought stress. Some important functional genes response to stress were induced by COR, which play a role in defense response of rice seedling to drought stress. This study is beneficial to clarify the molecular mechanism of COR to alleviate water stress in Rice.

\section{Results}

\subsection{Growth of Seedlings}

As may be seen from the photo of Nipponbare taken at $48 \mathrm{~h}$ after $17.5 \%$ polyethylene glycol (PEG) treatment (Figure 1), the changes of rice with different treatments were remarkable. Under drought conditions, most of the blade atrophied, and more leaves were rolled into the needle without COR treatment, while COR treatment did not. The data of weight have shown remarkable interaction between COR and PEG. At $7 \mathrm{~d}$ after PEG treatment, the dry weight of seedlings was significantly reduced by $37.6 \%$ for Nipponbare (Table 1), the fresh mass of rice treated with COR increased $83.7 \%$ under drought stress, while COR had no effect on seedling weight before the initiation of drought treatment. 


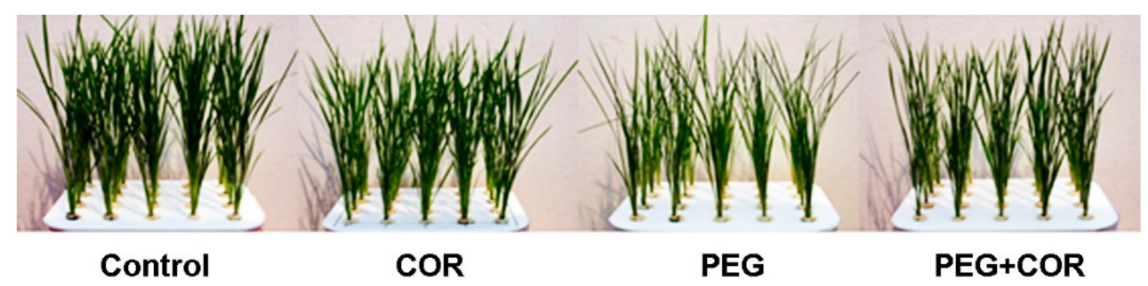

Figure 1. Effect of cornatine on Nipponbare rice seedlings under drought at $48 \mathrm{~h}$. Control, Normal conditions without COR and PEG treatment; PEG, Water deficit treatment induced by PEG for $10 \mathrm{~h}$ without COR pretreatment; COR+PEG, Pretreatment with $0.1 \mu \mathrm{M}$ COR for $12 \mathrm{~h}$ before PEG treatment; COR, Treatment with $0.1 \mu \mathrm{M}$ COR alone, without PEG treatment; the same for the following tables and figures.

Table 1. Effects of coronatine on biomass of Nipponbare rice seedlings under drought stress at seven days after the treatment.

\begin{tabular}{lcc}
\hline Treatment & Fresh Weight (g/plant) & Dry Weight (g/plant) \\
\hline Control & $0.727 \mathrm{a}$ & $0.101 \mathrm{a}$ \\
COR & $0.700 \mathrm{a}$ & $0.098 \mathrm{a}$ \\
PEG & $0.283 \mathrm{c}$ & $0.063 \mathrm{c}$ \\
PEG+COR & $0.520 \mathrm{~b}$ & $0.073 \mathrm{~b}$ \\
\hline
\end{tabular}

Values are means of four experiments each with three replications. Means within columns bearing the same letters are not significantly different $(p<0.05)$.

\subsection{Relative Water Content, Proline Content}

The RWC of rice were decreased under simulated drought stress (Figure 2a). After $72 \mathrm{~h}$ exposure to stress, the RWC of leaves (PEG and PEG+COR) were significantly lower than that in non-stressed seedlings (control and COR). However, leaves of the two cultivars under drought stress treated with COR maintained a much higher RWC than the non-treated COR, while, in normal treatments (control and COR), COR had little effect on the RWC. In Nipponbare cultivars, the data of proline content had shown remarkable interaction between COR and PEG (Figure 2b), and the content of proline increased sharply under drought with COR treatment.

A
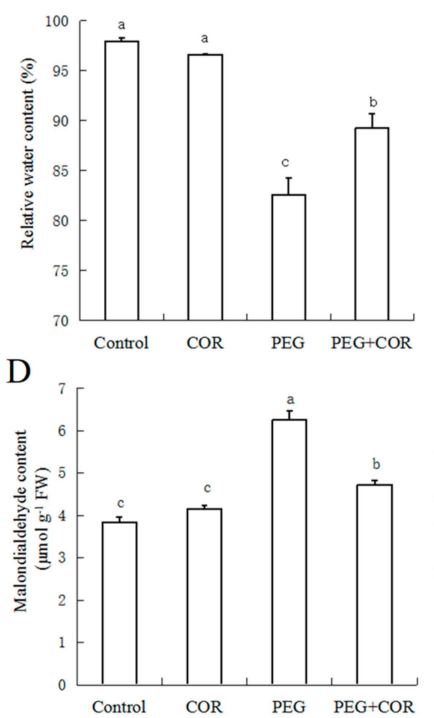

B

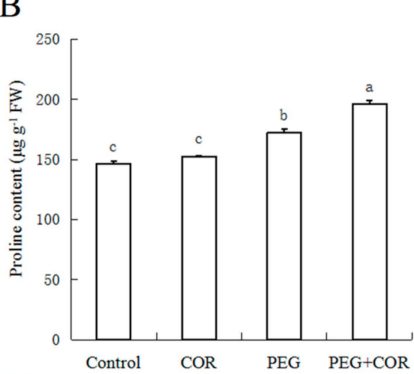

E

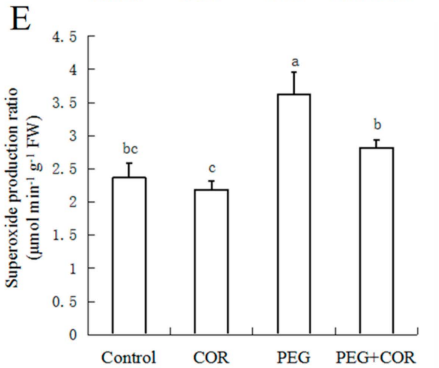

$\mathrm{C}$

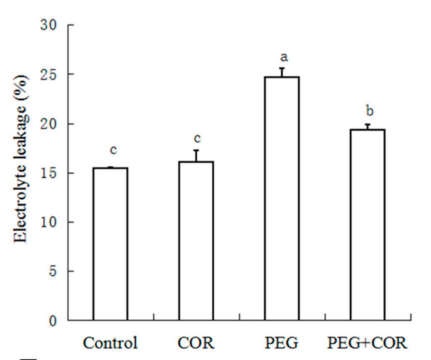

$\mathrm{F}$

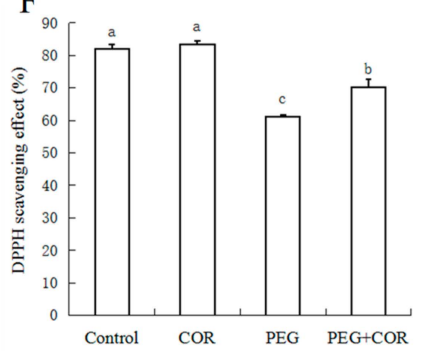

Figure 2. Effects of cornatine on relative water content (A), proline content (B), electrolyte leakage (C), MDA content (D), superoxide production ratio (E) and DPPH scavenging activity (F) in leaves of rice seedlings under drought condition at $3 \mathrm{~d}$. Values are means of four experiments each with three replications; bars with different letters are significantly different $(p<0.05)$. FW, fresh weight. 


\subsection{Relative Conductivity and MDA Content}

The data of relative conductivity had shown significant changes in rice among different treatments (Figure 2C); PEG-induced drought increased it obviously, but treatment with COR decreased the leakage considerably under drought stress by $21.7 \%$; without drought stress, the relative conductivity was little affected by COR.

Without drought stress, the MDA content in leaves was more or less similar for control and COR treatments, but the production of MDA increased sharply under drought, while COR pre-treatment reduced the production by $24.3 \%$ (Figure 2D).

\subsection{Superoxide Radical Estimation and DPPH-Radical Scavenging Activity}

Compared with the non-stressed plants, the rate of superoxide radical $\left(\bullet \mathrm{O}^{2-}\right)$ in seedlings under drought stress (PEG and PEG +COR) increased significantly (Figure 2E). COR did not affect the production of $\bullet \mathrm{O}^{2-}$ in leaves under sufficient water conditions; however, drought stress treatment with COR decreased it by $22.4 \%$.

The DPPH-radical scavenging effect in leaves was decreased by $25.4 \%$ due to drought stress, but the decrease was partially alleviated to $14.2 \%$ with COR pre-treatment (Figure $2 \mathrm{~F}$ ), while COR had no distinct effect under normal condition.

\subsection{Functional Analysis of the Transcriptome Map from Rice Nipponbare (Japonica) Treated by COR under} Normal and Drought Stress Conditions

In order to investigate what differences in Nipponbare were induced by COR in response to drought stress, sample probe sets were conducted with a microarray analysis using the Affymetrix rice whole genome array. The expression probe in the total chip probe is $38 \%$ to $40 \%$, the average was $38.82 \%$, and the present percent value was normal (Table 2). The percent of expressive probe was increased by $0.1 \%$ with COR under normal conditions, while the proportion of the probe to COR was decreased by $0.9 \%$ under drought stress. It indicated that the response of rice seedlings to COR treatment was different under different growth conditions.

Table 2. Percent of present probe in four treatments.

\begin{tabular}{lccc}
\hline Treatment & Total & Present & P Call (\%) \\
\hline Control & 57381 & 21806 & 38.00 \\
PEG & 57381 & 22827 & 39.78 \\
COR & 57381 & 21827 & 38.04 \\
PEG+COR & 57381 & 22632 & 39.44 \\
\hline
\end{tabular}

Based on the analysis of expressed genes using the software Cluster3.0, control and COR were clustered together, while PEG and PEG+COR treatments were clustered together. The red represents increased expression, and the deeper of the color stands for the larger of the upregulated expression amount. The green represents downregulated; the deeper the color is, the larger the down expression. There were 870 differentially expressed probes' responses to COR treatment, and 575 specific responses to COR under drought stress (Figure 3), which accounted for $66.09 \%$ of the total number of differentially expressed probes. 


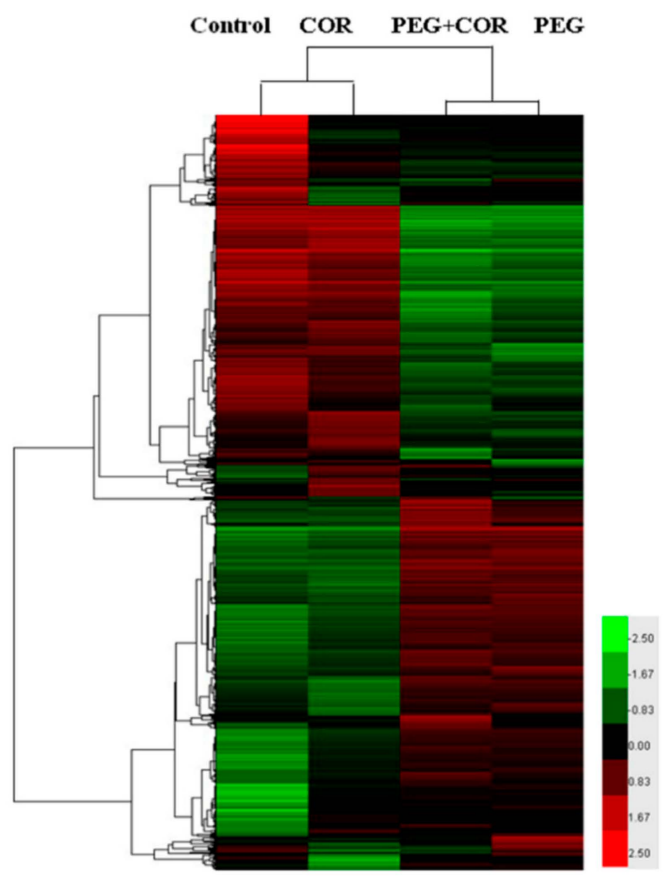

Figure 3. Effects of coronatine on the transcriptional profiles of rice leaf blades under drought stress. Cluster analysis of differential display genes response to COR under drought stress condition. Each column represents $\log 2$ ratio $(\mathrm{Cy} 5 / \mathrm{Cy} 3)$ of the different gene. The black color represents the ratio of 1:1; the red is for greater than $1: 1$.

According to the probe annotation of Rice Gene Chip, the results of differentially expressed genes on the function of classification using Gene Ontology (GO) classification showed that 49 (occupied $5.6 \%)$ probes did not have the corresponding known genes in all 870 differentially expressed probes, which may represent a new mutation in the gene-rich or 3 '-end and can not find homologous sequences; the other 821 probes were corresponding to 744 known genes, the functions of genes involve in stress response, signaling, metabolism, photosynthesis, organizational structure development, cell physiological and biochemical reactions, enzyme activity, cell membrane and other aspects (Figure 4).

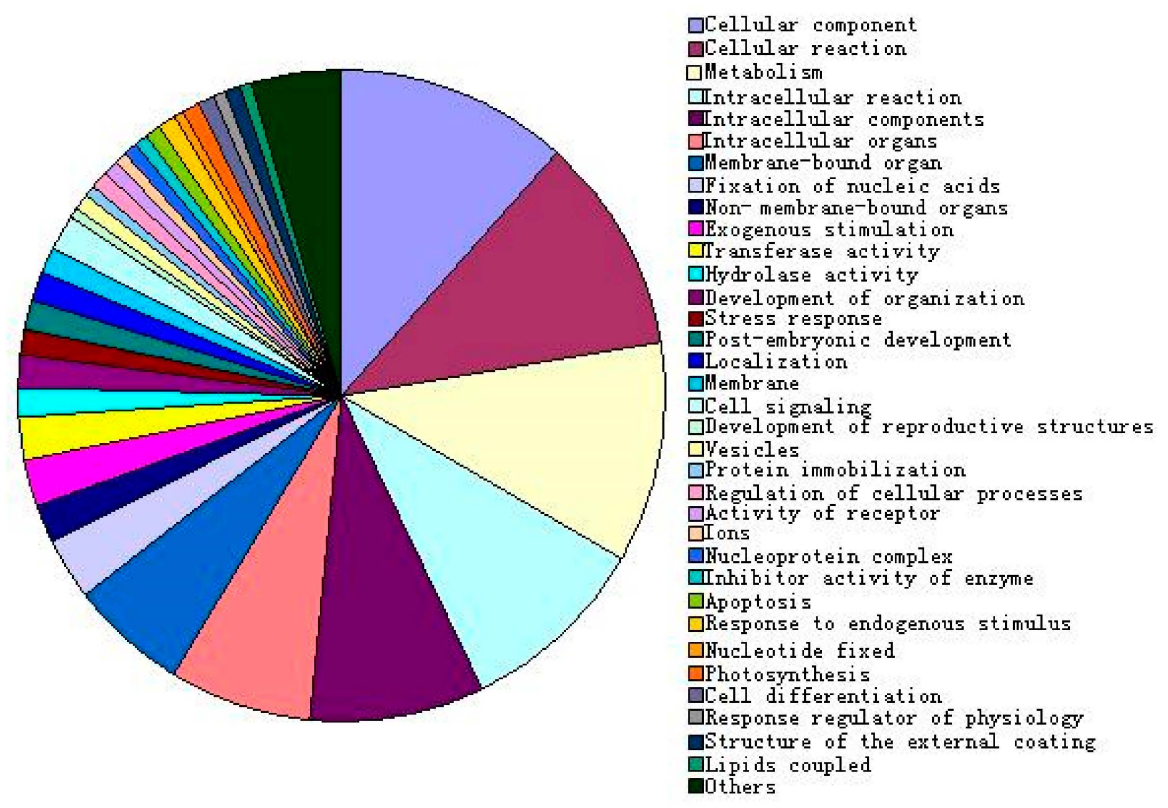

Figure 4. Function analysis of differential display genes response to cornatine under drought stress. 
Kyoto Encyclopedia of Genes and Genomes (KEGG) metabolic pathway analysis showed the function of differentially expressed gene response to COR involved in 20 metabolic pathways under drought stress, including riboflavin metabolism, amino sugar metabolism, alkaloid biosynthesis II, alanine, phenyl-alanyl Acid and aspartic acid metabolism, phenylalanine, tyrosine and tryptophan synthesis, synthesis of diterpene substances, caffeine metabolism, acid metabolism, photosynthesis, porphyrin and chlorophyll metabolism, methane metabolism, pyrimidine metabolism and ribosomes, glutamate metabolism, nicotine and nicotinamide metabolism, carbon fixation, phenyl acid synthesis, and $\gamma$-HCH degradation.

According to comprehensive GO classification and KEGG pathway analysis, the differentially expressed genes response to COR under drought stress were mainly related to the protein, carbohydrates, lipids, secondary metabolism and photosynthesis pathway and so on. In addition to the known response genes that were differentially expressed under drought stress, different stress response genes involved in oxidative stress, mechanical damage and biological stress, and other stresses, and genes associated with signal transduction, material transport, ion transport, carbohydrates, fat transfer and others related also responded to COR when exposed to drought (Table 3).

Table 3. Different expressing genes related to stress, transcription factor and others response to coronatine under drought stress.

\begin{tabular}{|c|c|c|c|}
\hline Catalogue & Gene Name & Fold Change & Annotation \\
\hline \multirow{12}{*}{ Response to Stress } & Os02g0572200 & 12.43 & Zn-finger, RING domain containing protein \\
\hline & Os06g0166500 & 4.98 & AUX/IAA protein family protein \\
\hline & Os09g0474000 & 4.18 & Basic-leucine zipper (bZIP) \\
\hline & Os07g0686800 & 3.36 & Serine/threonine protein kinase \\
\hline & Os09g0255400 & 3.06 & Indole-3-glycerol phosphate synthase (IGPS) \\
\hline & Os04g0578000 & 3.08 & ACC synthase \\
\hline & Os06g0549900 & 2.71 & FAD linked oxidase, $\mathrm{N}$-terminal domain containing protein \\
\hline & Os04g0511200 & 2.26 & EFA27 for EF hand, abscisic acid \\
\hline & Os09g0522000 & 0.49 & CBF-like protein \\
\hline & Os08g0474000 & 0.42 & AP2 domain containing protein RAP2.6 \\
\hline & Os01g0580500 & 0.25 & 1-aminocyclopropane-1-carboxylate oxidase \\
\hline & Os12g0139400 & 0.09 & Two-component response regulator ARR17 \\
\hline \multirow{9}{*}{$\begin{array}{l}\text { Transcription Factor } \\
\text { Gene }\end{array}$} & Os08g0520500 & 22.63 & Auxin response factor 2 \\
\hline & Os01g0298400 & 3.67 & MYB9 \\
\hline & Os09g0417800 & 3.31 & DNA-binding WRKY domain containing protein \\
\hline & Os03g0327800 & 3.19 & NAC-domain containing protein 29 (NAC2) \\
\hline & Os01g0826400 & 2.82 & WRKY transcription factor 24 \\
\hline & Os01g0904700 & 2.79 & Two-component response regulator ARR1 \\
\hline & Os03g0437200 & 2.52 & Transcription factor WRKY3 \\
\hline & Os04g0605100 & 2.20 & WRKY transcription factor 68 \\
\hline & Os02g0462800 & 2.18 & WRKY transcription factor 42 \\
\hline \multirow{11}{*}{$\begin{array}{l}\text { Correlate to } \\
\text { Photosynthesis and } \\
\text { Others }\end{array}$} & Os01g0597800 & 9.34 & UDP-glucuronosyl/UDP-glucosyltransferase family protein \\
\hline & Os03g0277700 & 9.28 & Protein of unknown function DUF26 domain \\
\hline & Os04g0447700 & 4.48 & NAD(P)H dependent 6 '-deoxychalcone synthase \\
\hline & Os06g0569500 & 3.40 & Ent-kaurene oxidase (AtKO1) ( Cytochrome P450 701A3) \\
\hline & Os06g0549900 & 2.71 & FAD linked oxidase, N-terminal domain containing protein \\
\hline & Os03g0709300 & 2.34 & Plastocyanin-like domain containing protein \\
\hline & Os02g0194700 & 2.26 & Plant lipoxygenase family protein \\
\hline & Os01g0600900 & 0.50 & Chlorophyll a-b binding protein 2 , chloroplast precursor \\
\hline & Os12g0292400 & 0.49 & Ribulose 1,5-bisphosphate carboxylase \\
\hline & Os03g0280000 & 0.43 & $\mathrm{ABC}$ transporter protein \\
\hline & Os07g0675400 & 0.16 & Aminoacyl-tRNA synthetase \\
\hline
\end{tabular}

2.6. The Differentially Expressed Genes Correlated to JA, ABA and Other Hormone Biosynthetic, and Signaling Pathway under Water Stress

Differentially expressed genes in microarray related to cell elongation, growth and stomatal closure were marked in different signaling pathways (Figure 5). The key elements of pathway were displayed in web-like network under COR treatment, and showed cross talk between JA, ETH, cytokinin (CTK), abscisic acid (ABA) and indole acetic acid (IAA) signaling pathways under drought stress. From 
our microarray results, OsWRKY3 (Os03g0437200) and OsWRKY24 (Os01g0826400) were upregulated induced by COR, and speculated to influence the pathway of JA and ABA which play crucial roles in multiple aspects of plant drought tolerance. The ETH was abundantly produced though a series of reactions accompanied by 1-aminocyclopropane-1- carboxylate (ACC) synthase (ACS, EC 4.4.1.14) (Os04g0578000) which was upregulated to maintain the balance of JA. OsNAC2 (Os03g0327800), the member of the NAC transcription factor family, might be similar to AtNAC2 and induced by auxin and mediates auxin signaling to promote the growth of plants. Furthermore, MYB/MYC transcription factors were activated by signaling molecules JA and stress response factors, which regulated the expression of downstream genes, in order to reduce the injury caused by stress [38-40]. Therefore, the differential expression of response genes may lead to different hormone signaling in addition to enhancing stress tolerance.

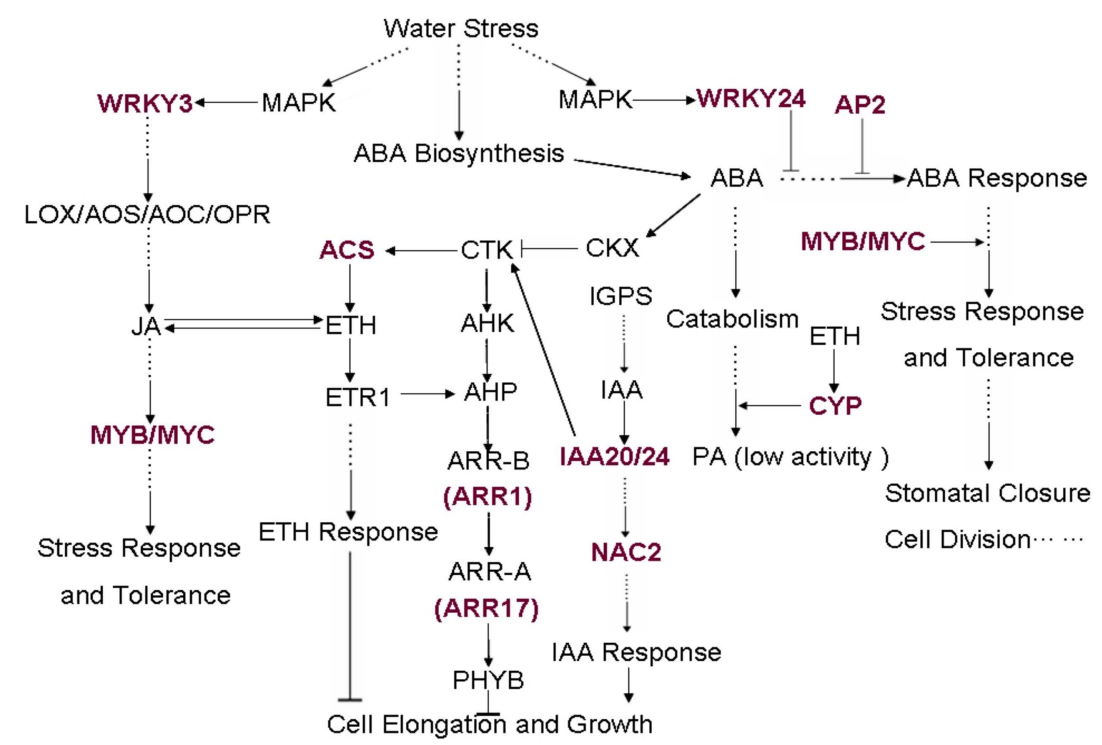

Figure 5. Gene net correlated to JA, ABA and other hormone biosynthetic, signaling and response pathway under water stress. The key elements of pathway are displayed in web-like network and are connected by arrows. A previously established link among IAA, ABA, Ethylene, CTK and cell elongation and growth is indicated. The red and overstriking words represent differentially expressed genes induced by COR in microarray. Arrows and t-bars represent positive and negative effects, respectively. Solid lines indicate effects that occur through direct interaction, whereas dotted lines indicate effects that have not yet been shown to occur through direct interaction.

\subsection{Real-Time Quantitative PCR (RT-qPCR) Verifies the Differential Expression of COR Regulated Genes}

To validate the expression results obtained using microarrays, we selected some candidate genes for real-time quantitative PCR (RT-qPCR) analysis to confirm our microarray. They include genes encoding MYB9, Zn-finger, UDP-glucuronosyl, WRKY transcription factor, cytochrome P450 and chalcone biosynthetic related genes. In order to do RT-qPCR validation, the biological samples are the same as what we used in microarray analysis. We designed gene-specific primers from the available full-length cDNAs and performed RT-qPCR (Figure 6). In general, RT-qPCR data are in agreement with the microarray expression data. Additionally, we examined a set of gene expression after drought treatment for the indicated time using RT-qPCR (Figure 7); the fold change of gene expression was maintained at a high level with COR treatment under early drought stress (about within $10 \mathrm{~h}$ ). ARF2 is a transcriptional suppressor that has been found to be involved in ethylene, auxin, and brassinosteroid pathway to control plant growth and development [41]. MYB is a large family that is involved in abiotic stress tolerance. There were different types such as MYB34, MYB15, MYB111, MYB33, MYB12, MYB4, MYB49, MYB52, MYB59, MYB57, MYB55, MYB70, MYB1, and MYB9 that were upregulated during low temperature stress in S. spontaneum [42]. Ethylene, which is 
interacted with abscisic acid, JA, IAA and SA to regulate stress tolerance, is produced from methionine (Met) via Sadenosylmethionine (AdoMet) by the action of ACC synthase (ACS) and ACC oxidase (ACO) [43]. NAD(P)H dependent 6'-deoxychalcone synthase (DCHS) could be characterized by the cellular activities involved in stress/defense, signal transduction, transport, protein folding, gene regulation, and primary metabolisms, which are critical for plant survival under stress [44]. We suggest that the increased expression of these genes is at least partially a result of enhanced drought tolerance of rice seedlings with COR treatment.

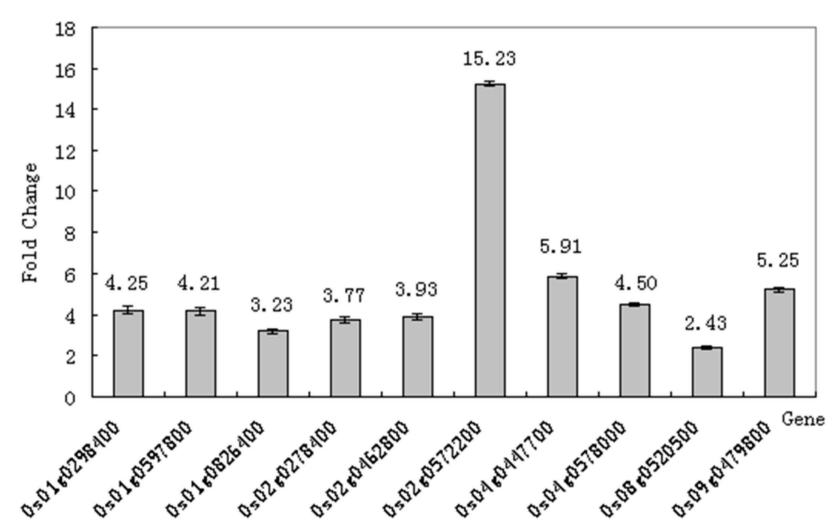

Figure 6. Transcriptional changes were analyzed using RT-qPCR. The expression gene annotation can be found in Table 3, the primers used for the RT-qPCR are presented in Table S1, while the fold change values represent the average of three independent biological replicates for comparison with microarray data, the actin gene was used as an internal control. Values are means of three experiments each with three replications; PEG, Water deficit treatment induced by PEG for $10 \mathrm{~h}$ without COR pretreatment; COR+PEG, Pretreatment with $0.1 \mu \mathrm{M}$ COR for $12 \mathrm{~h}$ before PEG treatment. The sample was collected $10 \mathrm{~h}$ after treatment.
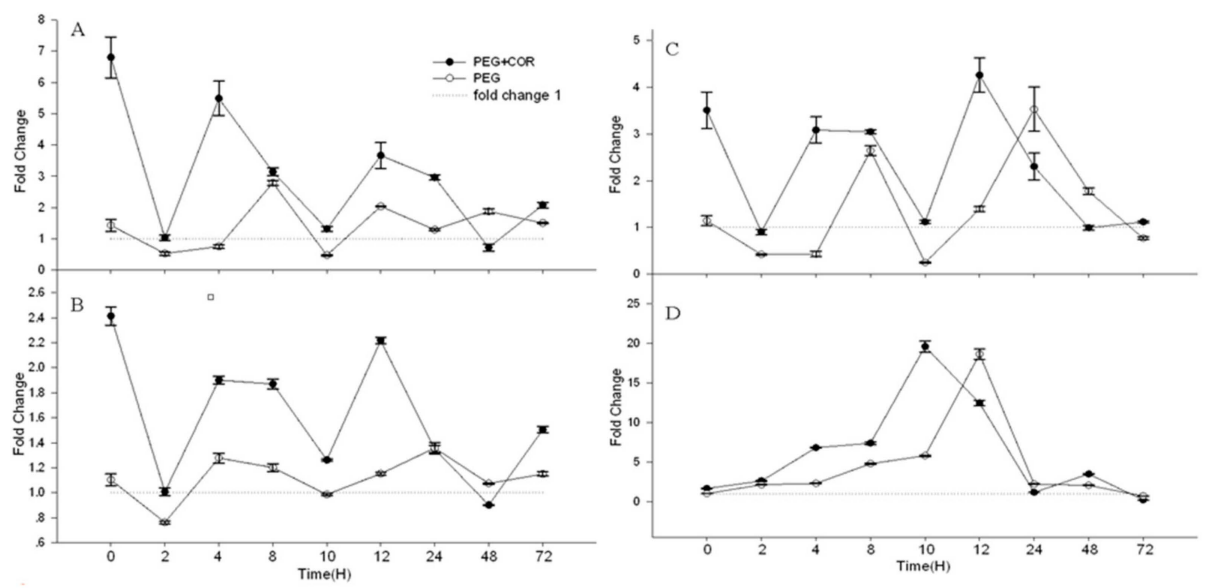

Figure 7. The changes of four genes expression in relation with the time. The expression data are presented for (A): Os01g0298400 (MYB9), (B): Os08g0520500 (ARF2), (C): Os04g0578000 (ACS) and (D): Os04g0447700 (DCHS). PEG, Water deficit treatment induced by PEG for $10 \mathrm{~h}$ without COR pretreatment; COR+PEG, Pretreatment with $0.1 \mu \mathrm{M}$ COR for $12 \mathrm{~h}$ before PEG treatment. The sample was collected in $2 \mathrm{~h}, 4 \mathrm{~h}, 8 \mathrm{~h}, 10 \mathrm{~h}, 12 \mathrm{~h}, 24 \mathrm{~h}, 48 \mathrm{~h}$, and $72 \mathrm{~h}$.

\section{Discussion}

Drought induces a plethora of additional cellular responses that are manifested in changes in whole plant transcriptome and metabolome [45-48], ultimately resulting in major changes in plant chemical composition. 


\subsection{Accumulation of Osmotica}

Accumulation of osmotica includes ubiquitous chemicals such as sugars and salt ions, and species-specific osmotica such as betaine, glycinebetaine, proline [49]. Proline has been recognized as a multi-functional molecule, accumulating in high concentrations to maintain sustainable growth in response to a variety of content abiotic stresses [50,51]. Pretreatment with COR increased the proline content significantly during drought stress (Figure 2). This is able to protect cells from damage by acting as both an osmotic agent and a radical scavenger. COR alleviated membrane damage by reducing electrolyte leakage and MDA under drought stress (Figure 2). In addition, the levels of superoxide radicals were sharply decreased with the pretreatment of COR under drought (Figure 2). High levels of DPPH-radical scavenging have been correlated with increased stress tolerance [52]. COR increased drought tolerance in rice seedlings through activation of DPPH-radical scavenging effect. As previously reported, COR treatment alleviated salt stress and drought stress by enhancing the activities of CAT, SOD, GPX and GR and the DPPH-radical scavenging capacity [21,37]. We speculated that the inducing effects of COR in water stress tolerance might involve the regulation and expression of functional genes.

\subsection{The Significant Expression of Response Genes}

The functions of differentially expressed genes induced by COR under drought stress are involved in stress response, signal transduction, metabolism and other aspects of organizational structure and development $[53,54]$. Genes encoding zinc finger proteins, ACC synthase, basic leucine zipper protein and calmodulin protein belong to responsive genes. Some drought stress-related zinc finger proteins have been found in rice, tobacco and barley and other plants $[55,56]$. ACC synthase plays a key role in the catalytic conversion of S-adenosyl-L-methionine (SAM) to ACC, and it is the rate-limiting enzyme of ethylene synthesis [57]. The accumulation of ethylene caused by a significant increase of ACS (Table 3, Figure 5) enhanced the stress response in plants [58,59]. Besides regulating plant growth and development, bZIP (b-zipper) and TFs (transcription factor) remain crucial concerning abiotic stress response such as drought, which is involved in ABA-dependent signal transduction pathways to reduce oxidative damage in Arabidopsis and tobacco under drought and high salt stress [60-62]. The calmodulin protein EFA27 also participates in rice dehydration, salt stress response process and the ABA signal transduction pathways [63]. AUX/IAA repressor and ARF transcription activator specifically bind together to regulate the expression of auxin response genes [64]. Under water stress, the significant expression of response genes (Table 3) may together participate in metabolite flux in order to enhance the resistance.

\subsection{Significantly Upregulated Transcription Factors Associated with Drought Tolerance}

TFs were found to play essential roles in multiple abiotic stress responses through binding to cis-regulatory elements in the promoter region of genes to regulating downstream stress-responsive genes $[54,65,66]$. Thus, genetic modification of the expression of these regulatory genes can greatly influence plant stress tolerance because they further regulate many downstream stress-responsive genes at a given time $[67,68]$. In our study, there are a total of 18 different types of the transcription factor gene family induced by COR that have been expressed differently under water stress. These genes may play an important part in the process of the drought stress signal transmission and regulation of drought stress response genes, which could be revealed in the presumptive pathway. A WRKY gene from a xerophytic evergreen C3 shrub, the creosote bush (Larrea tridentata), is an activator of ABA signaling [69]. The expression of WRKY TFs is induced rapidly when the plants are exposed to a variety of stresses signals including salicylic acid (SA) or other molecules [70,71]. WRKY3 regulates expression of JA biosynthesis genes (LOX, AOS, AOC and OPR), thereby increasing the levels of JA and JA-isoleucine, and in turn regulates directly and indirectly drought tolerance, while WRKY24 was found to act as regulators of an ABA-inducible promoter [72,73]. Therefore, significantly upregulated transcription 
factors (Table 3, Figure 5) induced by coronectin contribute to enhancing drought resistance of rice through ABA and JA levels.

\subsection{Changes of the Secondary Metabolic}

The secondary metabolism is the main adaptation mechanism of plants. Terpenoids, alkaloids, phenylpropanoid are the main types of secondary metabolites. Cytochrome, catalyzing the mono-oxidation reaction of many endogenous substrate and exogenous chemicals, is involved in GA deactivation and salt resistance in rice [74]. Cytochrome P450 (CYP) responded to SA significantly improved growth in drought-exposed Triticum aestivum seedlings [75]. Significantly upregulated CYP 450 (Table 3, Figure 5) induced by coronectine contributes to enhancing drought resistance of rice through the SA pathway.

According to the microarray results and the functional analysis of different gene expression induced by COR in drought conditions, we investigated the tolerant mechanism of rice seedling to drought stress. Some important transcription factors (MYB, WRKY TFs and bZIP TFs) related to stress response are activated or maintained in a high expression level with COR treatment under drought stress, and then may activate expression of genes functioning (calmodulin protein, ACC synthase and CYP 450) in metabolism, such as protein metabolism, carbohydrate metabolism, lipid metabolism, nucleic acid metabolism, photosynthesis and secondary metabolism, hormone content and in maintaining integrity of cell structural and the normal process of physiology. This study provides insights into alleviating water stress of COR in rice (Oryza sativa L.) cultivar nipponbare (Japonica), thus opening applications in the genetic improvement of drought tolerance in rice.

\section{Materials and Methods}

\subsection{Plant material, Growth Conditions and COR Treatments}

Coronatine was prepared as described in Palmer and Bender (1993) [76]. PEG-6 000 was provided by Sinopharm Chemical Reagent Company. Seeds of Rice (Oryza sativa L.) Nipponbare (Japonica) were soaked $36 \mathrm{~h}$ in advance disinfection before being sown in the sandbox, then cultured hydroponically in basins containing Kimura B nutrient solution from sandbox when seeds germinated and grew to two leaves in growth chamber characterized by $12 \mathrm{~h} / 12 \mathrm{~h}$ photoperiod, $28^{\circ} \mathrm{C} / 25^{\circ} \mathrm{C}$ day/night temperature, approximately $60 \%$ relative humidity and $400 \mu \mathrm{mol} \mathrm{m} \mathrm{m}^{-2} \mathrm{~s}^{-1}$ photon flux density. At the three leafed stage, $0.1 \mu \mathrm{mol} \mathrm{L-1} \mathrm{COR} \mathrm{were} \mathrm{added} \mathrm{to} \mathrm{the} \mathrm{solution.} \mathrm{Twelve} \mathrm{hours} \mathrm{after} \mathrm{treatment} \mathrm{with} \mathrm{COR,} \mathrm{some} \mathrm{of}$ the plants were subjected to water deficit induced by 17.5\% PEG-6 000 (-0.44 MPa) in the nutrient solution as the preliminary experiment selected. Each treatment was replicated three times, with three basins containing eighty strains of seedlings, and arranged into a completely randomized design. Ten hours after the drought treatment, plants of Nipponbare were sampled and immediately preserved in liquid nitrogen for Affymetric GeneChip analysis and RNA isolation. Three days after the drought treatment, plants were sampled and preserved by the same method for measurements of MDA level, electrolyte leakage, the activity of DPPH-radical scavenging, proline and relative water content. Seven days later, seedlings were sampled to measure the biomass.

\subsection{Relative Water Content (RWC), Proline Concentration of Leaves}

Three days after PEG treatment, the leaf RWC was measured on the youngest fully expanded leaves following the method of Sharp et al. [77]. Five plants were examined in each replication. Fresh weight $(\mathrm{FW})$ of leaves was determined immediately after harvest, and then leaf discs were allowed to float on distilled water until fully rehydrated. The discs were weighed for turgid weight (TW). The turgid leaves were dried in a hot air oven at $80^{\circ} \mathrm{C}$ to a constant weight and dry weight (DW) was recorded. The RWC of the leaves was calculated as: RWC $(\%)=(F W-D W) /(T W-D W) \times 100$. The method for determination of leaf proline content was according to Li [78]. 


\subsection{Measurements of Relative Conductivity and MDA Content}

Membrane permeability was determined by relative conductivity as described previously in Lutts et al. (1996) [79]. The third fully unfolded leaves were randomly selected from five seedlings and cut in $1 \mathrm{~cm}$ segments per replication, and a conductivity meter was used to measure the relative conductivity $(\mathrm{Lt} / \mathrm{L} 0)$. Tissue segments were placed in stoppered vials with $10 \mathrm{~mL}$ deionized water and incubated under dark at $25^{\circ} \mathrm{C}$ on a rotary shaker $(120 \mathrm{rpm})$. Twenty-four hours later, the electrical conductivity of the bath solution $(\mathrm{Lt})$ was measured. Samples were then autoclaved for $30 \mathrm{~min}$ to achieve $100 \%$ electrolyte leakage and a final conductivity reading (L0) was recorded upon equilibration at $25^{\circ} \mathrm{C}$. Analysis of electrolyte leakage was performed by relative conductivity of the bath solution before and after autoclaving the tissues.

The level of MDA production was used for estimating the lipid peroxidation. Fresh leaves $(0.5 \mathrm{~g})$ were homogenized in $4.0 \mathrm{~mL}$ of $10 \%$ trichloracetic acid (TCA) and centrifuged at 10,000 rpm for $10 \mathrm{~min}$ at $4{ }^{\circ} \mathrm{C}$. The supernatant was assayed for MDA following the method of Sairam and Srivastava (2001) [80].

\subsection{Superoxide Radical Estimation and DPPH-Radical Scavenging Activity}

The superoxide radical $(\bullet \mathrm{O} 2-)$ was measured by monitoring nitrite formation from hydroxylamine following the method of Verma and Mishra (2005) [81]. The DPPH-radical scavenging activity was determined according to procedures described by Kang and Saltveit (2002) [52].

\subsection{Affymetrix GeneChip Analysis}

Affymetric GeneChip hybridization was performed in CapitalBio Corp (Beijing, China). GeneChip Rice Genome Arrays were used for gene expression profile analysis in this study [82]. Affymetrix ${ }^{\circledR}$ Hybridization Oven 640 (Affymetrix, Inc. West Sacramento, CA, USA), Affymetrix ${ }^{\circledR}$ Fluidics Station 450 and Affymetrix ${ }^{\circledR}$ GeneChip ${ }^{\circledR}$ Scanner 3000 (Affymetrix, Inc., West Sacramento, CA, USA) were used in addition to CEL files that contained estimated probe intensity values, which exported from Affymetrix ${ }^{\circledR}$ GeneChip ${ }^{\circledR}$ Operating Software (Gcos1.4, Affymetrix, Inc. West Sacramento, CA, USA) platform. Software dChip (GDAS, Affymetrix, Inc., West Sacramento, CA, USA) $[83,84]$ was also used to further analysis the results of the data output from Gcos1.4. The annotation of probe sets was obtained from either Affymetrix or the Molecule Annotation System (MAS 3.0) (http://bioinfo.capitalbio.com/mas/) of CapitalBio Corporation.

\subsection{RNA Isolation and cDNA Preparation}

All seedling samples from Nipponbare were homogenized in liquid Nitrogen before isolation of RNA. Total RNA was isolated using TRIZOL ${ }^{\circledR}$ reagent (Invitrogen, CA, USA) and purified using Qiagen RNeasy columns (Qiagen, Hilden, Germany) according to the instructions of the manufacturer. Reverse transcription was performed using Moloney murine leukemia virus (M-MLV; Invitrogen). Briefly, $50 \mu \mathrm{g}$ of total RNA and $1 \mu \mathrm{L}$ of oligo d(T) primer $(1 \mathrm{pmol})$ were suspended in a final volume of $10 \mu \mathrm{L}$ with RNAse-OUT ${ }^{\mathrm{TM}}$ (Invitrogen). A master mix $(8 \mu \mathrm{L})$ containing $5 \times$ Superscript RT buffer (Invitrogen), dNTPs $(1 \mu \mathrm{L}$ containing $10 \mathrm{mmol}$ each dNTP), 0.1M DTT $(2 \mu \mathrm{L})$, and RNA-free ddH2O $(1 \mu \mathrm{L})$ was prepared and gently added to the RNA-RT mix. Each sample was heated for 3 min at $42{ }^{\circ} \mathrm{C}$, and $2 \mu \mathrm{L}(400 \mathrm{U})$ Superscript $\mathrm{II}^{\mathrm{TM}}$ reverse transcriptase (Invitrogen) was then added. The reaction was incubated at $42{ }^{\circ} \mathrm{C}$ for $1.5 \mathrm{~h}$, supplemented with $0.5 \mathrm{~mol} \mathrm{~L}-1$ EDTA $(3.5 \mu \mathrm{L})$, and then incubated at $65^{\circ} \mathrm{C}$ for $10 \mathrm{~min}$ to stop the reaction and hydrolyze template RNA.

\subsection{Real-Time Quantitative PCR (RT-qPCR) Analysis}

Three biologically independent replicates of RT-qPCR were conducted on 10 genes. Each replicate used aliquots of the same RNA samples used for microarrays. All gene-specific primers were designed by Primer 3 (http://frodo.wi.mit.edu/primer3/input.htm) using the full-length Oryza sativa L. cDNAs 
available from GenBank (Table S1), and the amplification of actin gene (Genbank: NM-197297) was used as an internal control to normalize all data. Real-time quantitative RT-PCR was performed on a 7500 real-time PCR system (Applied Biosystems, Foster, CA, USA) using SYBR ${ }^{\circledR}$ Premix Ex Taq ${ }^{\mathrm{TM}}$ (Perfect Real Time) (TaKaRa Code: DRR041A, Dalian, China). According to the manufacturer's protocol, $1.5 \mu \mathrm{L}$ cDNA, $0.4 \mu \mathrm{L}$ PCR forward/reverse primer $(10 \mu \mathrm{mol}), 10 \mu \mathrm{L} 2 \times$ SYBR $^{\circledR}$ Premix Ex Taq ${ }^{\mathrm{TM}}$ and $0.4 \mu \mathrm{L}$ ROX Reference Dye II (50×) were suspended in a final volume of $20 \mu \mathrm{L}$ with ddH2O. RT-qPCR cycling conditions consisted of an initial polymerase activation step at $95^{\circ} \mathrm{C}$ for $30 \mathrm{sec}, 40 \mathrm{cycles}$ of $5 \mathrm{sec}$ at $95^{\circ} \mathrm{C}$, and $35 \mathrm{sec}$ at $60^{\circ} \mathrm{C}$. Melt-curve analysis was performed to monitor primer-dimer formation and the amplification of gene specific products. The relative quantification method (DDCT) was used to evaluate quantitative variation between replicates examined.

\subsection{Statistical Analysis}

The experiment was repeated three times and, since no interactions occurred among repetitions, the results were pooled for analysis of variance following the general linear model of the Statistical Analysis System (SAS) (SAS Institute Inc., Cary, NC, USA). Treatment means were compared using the least significant difference test at the $5 \%$ level of probability.

\section{Perspectives}

Previous effects have showed that many drought-responsive genes, identified by RNA-seq and proteomics, have had their roles in alleviating water stress during water deficiency functionally confirmed. However, our understanding of gene expression profiles deciphering the pathways of Coronatine alleviating water stress in rice is just beginning. First, there are still many unresolved questions regarding the activity of COR in modulating phytohormone pathways. The main pathway of coronatine to alleviate water stress in rice needs to be explored more. Second, different drought-response genes have been identified, while their expression pattern, cellular or tissue localization, interactions and functions have not yet been reported. The function of most suppressed genes induced by COR remains unclear in drought conditions. Further analysis of COR-responsive genes and the potential receptors for COR needs to be investigated, which will help elucidate the mechanism of action for COR. Furthermore, the use of a gene editing approach to edit these functional genes for molecular breeding would also be beneficial.

Supplementary Materials: Supplementary materials can be found at http://www.mdpi.com/1422-0067/20/10/2543/s1. Author Contributions: Conceptualization, L.D.; Data curation, C.Y., L.A. and Y.Z.; Formal analysis, W.G. and L.A.; Methodology, W.G.; Supervision, L.D.; Writing—original draft, W.G. and C.Y.; Writing—review and editing, Y.Z. and L.D.

Funding: This research was supported by the National High Technology Research and Development Program of China, Grant No. 2011AA10A206.

Conflicts of Interest: The authors declare no conflict of interest.

\section{Abbreviations}

$\begin{array}{ll}\text { ABA } & \text { Abscisic acid } \\ \text { CAT } & \text { Catalase } \\ \text { CTK } & \text { Cytokinin } \\ \text { COR } & \text { Coronatine } \\ \text { DPPH } & \text { 2,2-Dipenyl-1- picrylhydrazyl } \\ \text { ETH } & \text { Ethylene } \\ \text { GR } & \text { Glutathione reductase } \\ \text { IAA } & \text { Indole acetic acid } \\ \text { LD } & \text { linear dichroism } \\ \text { MDA } & \text { Malondialdehyde } \\ \text { MeJA } & \text { Methyl jasmonic acid } \\ \text { PEG } & \text { Polyethylene glycol } \\ \text { POD } & \text { Peroxidase } \\ \text { RWC } & \text { Relative water content } \\ \text { SOD } & \text { Superoxide dismutase }\end{array}$




\section{References}

1. Todorov, D.; Alexieva, V.; Karanov, E. Effect of putrescine, 4-PU-30, and abscisic acid on maize plants grown under normal, drought, and rewatering conditions. J. Plant Growth Regul. 1998, 17, 197-203. [CrossRef] [PubMed]

2. Lukáš, K.; Miroslava, L.; Peter, V. Effect of osmotic stress in early stages of ontogenesis on root respiration, growth, sugar content, and cell injury in maize seedlings differing in drought sensitivity. J. Integr. Plant Biol. 2006, 48, 814-822.

3. Farooq, M.; Wahid, A.; Lee, D.J.; Ito, O.; Siddique, K.H.M. Advances in drought resistance of rice. Crit. Rev. Sci. 2009, 28, 199-217. [CrossRef]

4. Gigon, A.; Matos, A.R.; Laffray, D.; Zuily-Fodil, Y.; Pham-Thi, A.T. Effect of drought stress on lipid metabolism in the leaves of Arabidopsis thaliana (ecotype Columbia). Ann. Bot. 2004, 94, 345-351. [CrossRef] [PubMed]

5. Petrov, P.; Petrova, A.; Dimitrov, I.; Tashev, T.; Olsovska, K.; Brestic, M. Relationships between leaf morpho-anatomy, water status and cell membrane stability in leaves of wheat seedlings subjected to severe soil drought. J. Agron. Crop Sci. 2018, 204, 219-227. [CrossRef]

6. Ushimaru, T.; Shibasaka, M.; Tsuji, H. Resistance to oxidative injury in submerged rice seedlings after exposure to air. Plant Cell Physiol. 1994, 35, 211-218.

7. Jiang, M.Y.; Zhang, J.H. Effect of Abscisic acid on active oxygen species, antioxidative defence system and oxidative damage in leaves of maize seedlings. Plant Cell Physiol. 2001, 42, 1265-1273. [CrossRef]

8. Shao, L.; Shu, Z.; Sun, S.L.; Peng, C.L.; Wang, X.J.; Lin, Z.F. Antioxidation of anthocyanins in photosynthesis under high temperature stress. J. Integr. Plant Biol. 2007, 49, 1341-1351. [CrossRef]

9. Benard, F.J.; Runner, R.T.M. Erythrinaline alkaloids from the flowers and pods of Erythrina lysistemon and their DPPH radical scavenging properties. Phytochemistry 2004, 65, 1397-1401.

10. Cao, M.; Zhang, Y.; Liu, X.; Huang, H.; Zhou, X.E.; Wang, W.; Zeng, A.; Zhao, C.; Si, T.; Du, J.; et al. Combining chemical and genetic approaches to increase drought resistance in plants. Nat. Commun. 2017, 8, 1183. [PubMed]

11. Bender, C.L.; Alarcón-Chaidez, F.; Gross, D.C. Pseudomonas syringae phytotoxins: Mode of action, regulation and biosynthesis by peptide and polyketide synthetases. Microbiol. Mol. Biol. Rev. 1999, 63, $266-292$. [PubMed]

12. Cintas, N.A.; Koike, S.T.; Bull, C.T. A new pathovar, Pseudomonas syringae pv. Alisalensis pv nov., proposed for the causal agent of bacterial blight of broccoli and broccoli RAAB. Plant Dis. 2002, 86, 992-998. [CrossRef]

13. Mitchell, R.E. Coronatine production by some phytopathogenic pseudomonads. Physiol. Plant Pathol. 1982, 20, 83-89. [CrossRef]

14. Uppalapati, S.R.; Ayoubi, P.; Weng, H.; Palmer, D.A.; Mitchell, R.E.; Jones, W.; Bender, C.L. The phytotoxin coronatine and methyl jasmonate impact multiple phytohormone pathways in tomato. Plant J. 2005, 42, 201-217. [CrossRef]

15. Yan, J.; Zhang, C.; Gu, M.; Bai, Z.; Zhang, W.; Qi, T.; Cheng, Z.; Peng, W.; Luo, H.; Nan, F.; et al. The Arabidopsis CORONATINE INSENSITIVE1 Protein Is a Jasmonate Receptor. Plant Cell 2009, 21, 2220-2236. [CrossRef]

16. Brooks, D.M.; Bender, C.L.; Kunkel, B.N. The pseudomonas syringaephytotoxin coronatine promotes virulence by overcoming salicylic acid-dependent defences in Arabidopsis thaliana. Mol. Plant Pathol. 2005, 6, 629-639. [CrossRef] [PubMed]

17. Salzman, R.A. Transcriptional profiling of sorghum induced by methyl jasmonate, salicylic acid, and aminocyclopropane carboxylic acid reveals cooperative regulation and novel gene responses. Plant Physiol. 2005, 138, 352-368. [CrossRef] [PubMed]

18. Feys, B.J.F.; Benedetti, C.E.; Penfold, C.N.; Turner, J.G. Arabidopsis mutants selected for resistance to the phytotoxin coronatine are male sterile, insensitive to methyl jasmonate, and resistant to a bacterial pathogen. Plant Cell 1994, 6, 751-759. [CrossRef]

19. Lauchli, R.; Boland, W. Indanoyl amino acid conjugates: Tunable elicitors of plant secondary metabolism. Chem. Rec. 2003, 3, 12-21. [CrossRef] [PubMed]

20. Schüler, G.; Mithöfer, A.; Baldwin, I.T.; Berger, S.; Ebel, J.; Santos, J.G.; Herrmann, G.; Höscher, D.; Kramell, R.; Kutchan, T.M.; et al. Coronalon: A powerful, tool in plant stress physiology. FEBS Lett. 2004, 563, 17-22. [CrossRef] 
21. Xie, Z.X.; Duan, L.S.; Tian, X.L.; Wang, B.Q.; Eneji, A.E.; Li, Z.H. Coronatine alleviates salinity stress in cotton by improving the antioxidative defense system and radical-scavenging activity. J. Plant Physiol. 2008, 165, 375-384.

22. Yan, Z.F.; Wei, J.K.; Zhou, X. Effects on the resistance water stress for India millet seedling by coronatine treatment. Chin. Agric. Sci. Bull. 1999, 15, 11-14.

23. Wang, B.Q.; Li, Z.H.; Eneji, A.E.; Tian, X.L.; Zhai, Z.X.; Li, J.M.; Duan, L.S. Effects of coronatine on growth, gas exchange traits, chlorophyll content, antioxidant enzymes and lipid peroxidation in maize (Zea mays L.) seedlings under simulated drought stress. Plant Prod. Sci. 2008, 11, 283-290. [CrossRef]

24. Li, X.W.; Shen, X.F.; Li, J.M.; Eneji, A.E.; Li, Z.H.; Tian, X.L.; Duan, L.S. Coronatine alleviates water deficiency stress on winter wheat seedlings. J. Integr. Plant Biol. 2010, 52, 616-625. [CrossRef]

25. Zhou, Y.Y.; Liu, Y.R.; Peng, C.X.; Li, X.W.; Zhang, M.C.; Tian, X.L.; Li, J.M.; Li, Z.H.; Duan, L.S. Coronatine enhances drought tolerance in winter wheat by maintaining high photosynthetic performance. J. Plant Physiol. 2018, 228, 59-65. [CrossRef] [PubMed]

26. Shen, X.F.; Chen, Y.; Li, J.M.; Duan, L.S. Coronatine effects on yield, nutrient uptake, and physio-biochemical attributes of soybean roots. J. Plant Nutr. 2018, 41, 664-671. [CrossRef]

27. Wu, H.L.; Wu, X.L.; Li, Z.H.; Duan, L.S.; Zhang, M.C. Physiological evaluation of drought stress tolerance and recovery in cauliflower (Brassica oleracea L.) seedlings treated with methyl jasmonate and coronatine. J. Plant Growth Regul. 2012, 31, 113-123. [CrossRef]

28. Tamogami, S.; Kodama, O. Coronatine elicits phytoalexin production in rice leaves (Oryza sativa L.) in the same manner as jasmonic acid. Phytochemistry 2000, 54, 689-694. [CrossRef]

29. Chini, A.; Fonseca, S.; Fernández, G.; Adie, B.; Chico, J.M.; Lorenzo, O.; García-Casado, G.; López-Vidriero, I.; Lozano, F.M.; Ponce, M.R.; Micol, J.L.; Solano, R. The JAZ family of repressors is the missing link in jasmonate signaling. Nature 2007, 448, 666-671. [CrossRef]

30. Montesano, M.; Brader, G.; Palva, E.T. Pathogen derived elicitors: Searching for receptors in plants. Mol. Plant Pathol. 2003, 4, 73-79. [CrossRef]

31. Lu, H.; Greenberg, J.T.; Holuigue, L. Salicylic acid signaling networks. Front. Plant Sci. 2016, 7, 238. [CrossRef]

32. Glazebrook, J.; Chen, W.Q.; Estes, B.; Chang, H.S.; Nawrath, C.; Métraux, J.P. Topology of the network integrating salicylate and jasmonate signal transduction derived from global expression phenotyping. Plant J. 2003, 34, 217-228. [CrossRef]

33. Littleson, M.M.; Baker, C.M.; Dalençon, A.J.; Frye, E.C.; Jamieson, C.; Kennedy, A.R.; Ling, K.B.; McLachlan, M.M.; Montgomery, M.G.; Russell, C.J.; et al. Scalable total synthesis and comprehensive structure-activity relationship studies of the phytotoxin coronatine. Nat. Commun. 2018, 9, 1105. [CrossRef]

34. Lin, A.I.; Zhao-Hu, L.I.; Jian-Min, L.I.; Xiao-Li, T.I.; Bao-Min, W.A.; Zhi-Xi, Z.H.; Liu-Sheng, D.U. Inducing effect of plant growth substance coronatine on drought tolerance of upland and lowland rice seedlings and its physiological mechanism. Chin. J. Rice Sci. 2008, 22, 443-446.

35. Braun, Y.; Smirnova, A.; Weingart, H.; Schenk, A.; Ullrich, M. Coronatine gene expression in vitro and in planta, and protein accumulation during temperature downshift in Pseudomonas syringae. Sensors 2009, 9, 4272-4285. [CrossRef]

36. Geng, X.; Jin, L.; Shimada, M.; Kim, M.G.; Mackey, D. The phytotoxin coronatine is a multifunctional component of the virulencen armament of Pseudomonas syringae. Planta 2014, 240, 1149-1165. [CrossRef]

37. Ai, L.; Li, Z.H.; Xie, Z.X.; Tian, X.L.; Eneji, A.E.; Duan, L.S. Coronatine alleviates polyethylene glycol-induced water stress in two rice (Oryza sativa L.) cultivars. J. Agron. Crop Sci. 2008, 194, 360-368. [CrossRef]

38. Byrne, M.E.; Barley, R.; Curtis, M.; Arroyo, J.M.; Dunham, M.; Hudson, A.; Martienssen, R.A. Asymmetric leaves1 mediates leaf patterning and stem cell function in Arabidopsis. Nature 2000, 408, 967-971. [CrossRef] [PubMed]

39. Vannini, C.; Locatelli, F.; Bracale, M.; Magnani, E.; Marsoni, M.; Osnoto, M. Overexpression of the rice Osmyb4 gene increases chilling and freezing tolerance of Arabidopsis thaliana plants. Plant J. 2004, 37, $115-127$. [CrossRef]

40. Cominelli, E.; Gusmaroli, G.; Allegra, D.; Galbiati, M.; Wade, H.K.; Jenkins, G.I.; Tonelli, C. Expression analysis of anthocyanin regulatory genes in response to different light qualities in Arabidopsis thaliana. J. Plant Physiol. 2008, 165, 886-894. [CrossRef] 
41. Wang, L.; Hua, D.; He, J.; Duan, Y.; Chen, Z.; Hong, X.; Gong, Z. Auxin Response Factor2 (ARF2) and its regulated homeodomain gene HB33 mediate abscisic acid response in Arabidopsis. PLoS Genet. 2011, 7, e1002172. [CrossRef]

42. Selvarajan, D.; Mohan, C.; Dhandapani, V.; Nerkar, G.; Jayanarayanan, A.N.; Mohanan, M.V.; Murugan, N.; Kaur, L.; Chennappa, M.; Kumar, R.; et al. Differential gene expression profiling through transcriptome approach of Saccharum spontaneum L. under low temperature stress reveals genes potentially involved in cold acclimation. Biotech 2018, 8, 195. [CrossRef] [PubMed]

43. Bürstenbinder, K.; Rzewuski, G.; Wirtz, M.; Hell, R.; Sauter, M. The role of methionine recycling for ethylene synthesis in Arabidopsis. Plant J. 2007, 49, 238-249. [CrossRef]

44. Zhen, Y.; Qi, J.L.; Wang, S.S.; Su, J.; Xu, G.H.; Zhang, M.S.; Miao, L.V.; Peng, X.X.; Tian, D.; Yang, Y.H. Comparative proteome analysis of differentially expressed proteins induced by $\mathrm{Al}$ toxicity in soybean. Physiol. Plant. 2007, 131, 542-554. [CrossRef] [PubMed]

45. Ramakrishna, A.; Ravishankar, G.A. Influence of abiotic stress signals on secondary metabolites in plants. Plant Signal. Behav. 2011, 6, 1720-1731.

46. Arbona, V.; Manzi, M.; Ollas, C.; Gómez-Cadenas, A. Metabolomics as a tool to investigate abiotic stress tolerance in plants. Int. J. Mol. Sci. 2013, 14, 4885-4911. [CrossRef]

47. Xu, Y.; Gao, S.; Yang, Y.; Huang, M.; Cheng, L.; Wei, Q.; Fei, Z.; Gao, J.; Hong, B. Transcriptome sequencing and whole genome expression profiling of chrysanthemum under dehydration stress. BMC Genom. 2013, 14, 662. [CrossRef]

48. Zhang, J.Y.; Cruz De Carvalho, M.H.; Torres-Jerez, I.V.; Kang, Y.U.; Allen, S.N.; Huhman, D.V.; Tang, Y.; Murray, J.; Sumner, L.W.; Udvardi, M.K. Global reprogramming of transcription and metabolism in M edicago truncatula during progressive drought and after rewatering. Plant Cell Environ. 2014, 37, 2553-2576. [CrossRef]

49. Morales, C.G.; Pino, M.T.; Del Pozo, A. Phenological and physiological responses to drought stress and subsequent rehydration cycles in two raspberry cultivars. Sci. Hortic. 2013, 162, 234-241. [CrossRef]

50. Liu, E.E.; Zong, H.; Guo, Z.F.; Li, Y.C. Effects of drought, salt and chilling stress on proline accumulation in shoot of rice seedlings. J. Trop. Subtrop. Bot. 2000, 8, 235-258.

51. Kavi Kishor, P.B.; Sreenivasulu, N. Is proline accumulation per se correlated with stress tolerance or is proline homeostasis a more critical issue? Plant Cell Environ. 2014, 37, 300-311. [CrossRef]

52. Kang, H.M.; Saltveit, M.E. Reduced chilling tolerance in elongating cucumber seedling radicals is related to their reduce antioxidant enzyme and DPPH-radical scavenging activity. Physiol. Plant. 2002, 115, 244-250. [CrossRef] [PubMed]

53. Todaka, D.; Shinozaki, K.; Yamaguchi-Shinozaki, K. Recent advances in the dissection of drought-stress regulatory networks and strategies for development of drought-tolerant transgenic rice plants. Front. Plant Sci. 2015, 6, 84. [CrossRef]

54. Joshi, R.; Wani, S.H.; Singh, B.; Bohra, A.; Dar, Z.A.; Lone, A.A.; Pareek, A.; Singla-Pareek, S.L. Transcription factors and plants response to drought stress: Current understanding and future directions. Front. Plant Sci. 2016, 7, 1029. [CrossRef] [PubMed]

55. Sugano, S.; Kaminaka, H.; Rybka, Z.; Catala, R.; Salinas, J.; Matsui, K.; Ohme-Takagi, M.; Takatsuji, H. Stress-responsive zinc finger gene ZPT2-3 plays a role in drought tolerance in petunia. Plant J. 2003, 36, 830-841. [CrossRef] [PubMed]

56. Sakamoto, H.; Maruyama, K.; Sakuma, Y.; Meshi, T.; Iwabuchi, M.; Shinozaki, K.; Yamaguchi-Shinozaki, K. Arabidopsis Cys/His-type zinc-finger proteins function as transcription repressors under drought, cold, and high-salinity stress conditions. Plant Physiol. 2004, 136, 2734-2746. [CrossRef]

57. Dong, J.G. Cloning of a cDNA encoding 1-aminocyclop ropane-1-carboxylate synthase and expression of its mRNA in ripening apple fruit. Planta 1991, 185, 38-45. [CrossRef] [PubMed]

58. Schlagnhaufer, C.; Arteca, R.; Pell, E. Sequential expression of two 1-aminocyclop ropane-1-carboxylate synthase gene in response to biotic and abiotic stresses in potato leaves. Plant Mol. Biol. 1997, 35, 683-688. [CrossRef]

59. Olson, D.C.; White, J.A.; Edelman, L.; Harkins, R.N.; Kende, H. Differential expression of two genes for 1-aminocyclop ropane-1-carboxylic acid synthase in tomato fruits. Proc. Natl. Acad. Sci. USA 1991, 88, 5340-5344. [CrossRef] 
60. Guiltinan, M.J.; Marcotte, J.W.R.; Quatrano, R.S. A plant leucine zipper protein that recognizes an abscisic acid response element. Science 1990, 250, 267-271. [CrossRef]

61. Llorca, C.M.; Potschin, M.; Zentgraf, U. bZIPs and WRKYs: Two large transcription factor families executing two different functional strategies. Front. Plant Sci. 2014, 5, 169. [CrossRef] [PubMed]

62. Fátima, C.A.; Sônia, M.B.C.; Júlio, C.M.C.; Nunes, C.C.; Martinez, C.A.; Otoni, W.C.; Fontes, E.P.B. Enhanced accumulation of BiP in transgenic plants confers tolerance to water stress. Plant Physiol. 2001, 126, 1042-1054.

63. Reddy, A.S.N. Calcium: Silver bullet in signaling. Plant Sci. 2001, 160, 381-404. [CrossRef]

64. Hagen, G.; Guilfoyle, T. Auxin-responsive gene expression: Genes, promoters and regulatory factors. Plant Mol. Biol. 2002, 49, 373-385. [CrossRef]

65. Nuruzzaman, M.; Sharoni, A.M.; Kikuchi, S. Roles of NAC transcription factors in the regulation of biotic and abiotic stress responses in plants. Front. Microbiol. 2013, 4, 248. [CrossRef] [PubMed]

66. Franco-Zorrilla, J.M.; López-Vidriero, I.; Carrasco, J.L.; Godoy, M.; Vera, P.; Solano, R. DNA-binding specificities of plant transcription factors and their potential to define target genes. Proc. Natl. Acad. Sci. USA 2014, 111, 2367-2372. [CrossRef] [PubMed]

67. Wang, H.; Wang, H.; Shao, H.; Tang, X. Recent advances in utilizing transcription factors to improve plant abiotic stress tolerance by transgenic technology. Front. Plant Sci. 2016, 7, 67. [CrossRef]

68. Shao, H.; Wang, H.; Tang, X. NAC transcription factors in plant multiple abiotic stress responses: Progress and prospects. Front. Plant Sci. 2015, 6, 902. [CrossRef] [PubMed]

69. Zou, X.L.; Seemann, J.R.; Neuman, D.; Shen, Q.J. A WRKY gene from creosote bush encodes an activator of the abscisic acid signaling pathway. J. Biol. Chem. 2004, 279, 55770-55779. [CrossRef] [PubMed]

70. Song, Y.; Ai, C.; Jing, S.; Yu, D. Research progress on functional analysis of rice WRKY genes. Rice Sci. 2010, 17, 60-72. [CrossRef]

71. Rushton, P.J.; Somssich, I.E.; Ringler, P.; Shen, Q.J. WRKY transcription factors. Plant Signal. Behav. 2014, 9, e27700. [CrossRef]

72. Xie, Z.; Ruas, P.; Shen, Q.J. Regulatory networks of phytohormone abscisic acid. Vitam. Horm. 2005, 72, 235-269. [PubMed]

73. Xie, Z.; Zhang, Z.L.; Zou, X.L.; Huang, J.; Ruas, P.; Thompson, D.; Shen, Q.J. Annotations and functional analyses of the rice WRKY gene superfamily reveal positive and negative regulators of abscisic acid signaling in aleurone cells. Plant Physiol. 2005, 137, 176-189. [CrossRef] [PubMed]

74. Wang, C.; Yang, Y.; Wang, H.; Ran, X.; Li, B.; Zhang, J.; Zhang, H. Ectopic expression of a cytochrome P450 monooxygenase gene PtCYP714A3 from Populus trichocarpa reduces shoot growth and improves tolerance to salt stress in transgenic rice. Plant Biotechnol. J. 2016, 14, 1838-1851. [CrossRef] [PubMed]

75. Ullah, A.; Manghwar, H.; Shaban, M.; Khan, A.H.; Akbar, A.; Ali, U.; Ali, E.; Fahad, S. Phytohormones enhanced drought tolerance in plants: A coping strategy. Environ. Sci. Pollut. Res. 2018, 25, 33103-33118. [CrossRef]

76. Palmer, D.A.; Bender, C.L. Effects of environmental and nutritional factors on production of the polyketide phytotoxin coronatine by Pseudomonas syringae pv. Glycinea. Appl. Environ. Microbiol. 1993, 59, 1619-1626. [PubMed]

77. Sharp, R.E.; Hsiao, T.C.; Silk, W.K. Growth of the maize primary root at low water potentials. II. Role of growth and deposition of hexose and potassium in osmotic adjustment. Plant Physiol. 1990, 93, 1337-1348. [CrossRef] [PubMed]

78. Li, H.S. Plant Physiology and Biochemistry Experiment Principle and Technology; Higher Education Press: Beijing, China, 2000.

79. Lutts, S.; Kinet, J.M.; Bouharmont, J. NaCl-induced senescence in leaves of rice (Oryza sativa L.) cultivars differing in salinity resistance. Ann. Bot. 1996, 78, 389-398. [CrossRef]

80. Sairam, R.K.; Srivastava, G.C. Water stress tolerance of wheat (Triticum aestivum L.): Variations in hydrogen peroxide accumulation and antioxidant activity in tolerant and susceptible genotypes. J. Agron. Crop Sci. 2001, 186, 63-70. [CrossRef]

81. Verma, S.; Mishra, S.N. Putrescine alleviation of growth in salt stressed Brassica juncea by inducing antioxidative defense system. J. Plant Physiol. 2005, 162, 669-677. [CrossRef]

82. Liu, F.X.; Xu, W.Y.; Wei, Q.; Zhang, Z.H.; Tan, L.B.; Di, C. Gene expression profiles deciphering rice phenotypic variation between Nipponbare (Japonica) and 93-11 (Indica) during oxidative stress. PLoS ONE 2010, 5, e8632. [CrossRef] 
83. Li, C.; Wong, W.H. Model-based analysis of oligonucleotide arrays: Expression index computation and outlier detection. Proc. Natl. Acad. Sci. USA 2001, 98, 31-36. [CrossRef] [PubMed]

84. Li, C.; Wong, W.H. Model-based analysis of oligonucleotide arrays: Model validation, design issues and standard error application. Genome Biol. 2001, 2, RESEARCH0032. [PubMed]

(C) 2019 by the authors. Licensee MDPI, Basel, Switzerland. This article is an open access article distributed under the terms and conditions of the Creative Commons Attribution (CC BY) license (http://creativecommons.org/licenses/by/4.0/). 